\title{
Development of Canine Chronic Kidney Disease Model: A Pilot Study
}

\author{
Tahany A Ismail ${ }^{1}$, Haithem A Farghali ${ }^{2}$, Marwa S Khattab ${ }^{3 *}$, Essam M Ibrahem ${ }^{1}$, Dina Sabry ${ }^{4}$ and \\ Hala MF ElMiniawy ${ }^{3}$ \\ ${ }^{1}$ Animal Health Research Institute, Doki Giza, Egypt \\ ${ }^{2}$ Department of Surgery, Anesthesiology and Radiology Department, Faculty of Veterinary Medicine, Cairo University, Egypt \\ ${ }^{3}$ Department of Pathology, Faculty of Veterinary Medicine, Cairo University, Egypt \\ ${ }^{4}$ Medical Biochemistry and Molecular Biology, Department Faculty of Medicine, Cairo University, Egypt \\ *Corresponding author: marwakhattab@cu.edu.eg
}

\begin{abstract}
Article History: 20-248 Received: 21-Dec-20 Revised: 26-Mar-20 Accepted: 10-Apr-20
\section{ABSTRACT}

Chronic kidney disease (CKD) is a worldwide health problem with a poor prognosis. The exploration of possible medical intervention requires the presence of a suitable animal model. This work aims to induce a model of canine CKD with persistent uremia. Three dogs were used to develop canine CKD models with different techniques based on the remnant kidney model. Model (1) was subjected to excision of one renal pole of the right kidney. Model (2) was subjected to the excision of two renal poles of the right kidney. Model (3) underwent ligation of two renal arterial branches of the right kidney. A contralateral nephrectomy was performed in the three models after two weeks from the first operation. Blood and 24-hour urine samples were collected weekly to determine renal function parameters. Histopathology, Immunohistochemistry of $\alpha$-SMA expression, and quantitative real-time PCR for Kim-1 \& NGAL gene expression were performed on kidney tissues. According to the IRIS staging system in dogs, model (1) represented stage one of CKD with less expression of genes and $\alpha$-SMA in the interstitial tissue. Model (2) represented stage three of CKD with moderate expression of genes and $\alpha$-SMA and moderate glomerulointerstitial nephritis. Model (3) suffered from severe uremia. It showed the highest expression of genes and $\alpha$-SMA with severe glomerulointerstitial nephritis and infarction. Therefore, model (2) was considered the best technique for developing a model of canine CKD with persistent uremia. The dog in this model became uremic and remained stable for a long time which would allow experimental manipulation.
\end{abstract}

Key words: Canine chronic kidney disease (CKD), Remnant kidney models, Histopathology, Kim-1 \& NGAL genes.

(C202I IJVS - All Rights Reserved

\section{INTRODUCTION}

Chronic kidney disease (CKD) has become a public health problem and reached an epidemic level due to increased prevalence of diabetes mellitus, hypertension, and obesity (Ruiz-Ortega et al. 2020; Lorsirigool and Pumipuntu 2020). The number of patients with CKD worldwide is estimated to double from 2010 to 2030 (Chen et al. 2017). $\mathrm{CKD}$ is an irreversible and progressive deterioration of renal function, resulting from a decreased number of functional nephrons (Togel et al. 2008). It is characterized by tubulointerstitial inflammation, tubular atrophy, and interstitial fibrosis with subsequent progressive loss of renal function (Mcleland et al. 2014; Sparkes et al. 2016; Vázquez-Méndez et al. 2020). CKD and End-stage kidney disease (ESKD) are caused by multifactorial etiologies such as chronic glomerulonephritis, type 2 diabetic nephropathy, and hypertensive nephrosclerosis (Tomino 2014). Congenital renal diseases, including dysplasia and various glomerulopathies, may produce CKD in pet animals at a very early age (Chakrabarti et al. 2013).

Experimental models of CKD are obtained by the administration of drugs such as gentamicin, and adenosine (Sun et al. 2011) or surgically by the remnant kidney model (Chow et al. 2003). The remnant kidney model is defined as a procedure in which some portions of renal mass are removed or damaged while leaving other portions intact (Devada et al. 2012). Two main methods are used to induce remnant kidney model; surgical excision of some portions of renal mass with unilateral nephrectomy or by infarction through ligation of a variable number of interlobular arteries with unilateral nephrectomy (Liu et al. 2003).

Cite This Article as: Ismail TA, Farghali HA, Khattab MS, Ibrahem EM, Sabry D and ElMiniawy HMF, 2021. Development of canine chronic kidney disease model: A pilot study. International Journal of Veterinary Science 10(4): 286-293. https://doi.org/10.47278/journal.ijvs/2021.056 
Experimental studies of progressive renal disease mainly used the remnant kidney model (Chow et al. 2003). This model has been applied in rats (Wang et al. 2017) mice (Yu et al. 2016), dogs (Finco et al. 2004) and cats (Adams et al. 1994). The purpose of the present study is to develop an experimental model of CKD in dogs in three different ways based on the remnant kidney nephrectomy model which would allow the future investigation of possible treatments.

\section{MATERIALS AND METHODS}

This study has been approved by the Institutional Animal Care and Use Committee, Faculty of Veterinary Medicine, Cairo University, Egypt (Approval No. Vet CU 16072020199).

\section{Animals}

A total of 3 male Mongrel dogs (age: 2-3 years; weight: $20-25 \mathrm{~kg}$ ) were used in this study. They were housed in kennels of Surgery, Anesthesiology and Radiology Department, Faculty of Veterinary Medicine, Cairo University, and maintained at a constant temperature. Animals were fed a standard diet and had free access to drinking water.

\section{Surgical Technique \\ Preoperative Preparation}

Each dog was subjected to ore-anesthetic laboratory screening; a complete blood cell count, serum biochemistry, and urinalysis to evaluate the general health conditions and normal kidney function of the animals under the experiment and to detect subclinical disease such as hypoproteinemia and anemia that may affect the animal response to anesthesia (Mitchell et al. 2018). Complete aseptic preoperative preparations of the operation site were done according to Bigliardi et al. (2017).

\section{Anesthesia}

Each dog was pre-medicated with atropine sulfate (Atropine sulphate ${ }^{\circledR} 1 \%$, Adwia Co., Egypt) at a dose of $0.1 \mathrm{mg} / \mathrm{kg} \mathrm{BW}$ given subcutaneously and xylazine $\mathrm{HCl}$ (Xyla-Ject@ 2\%, Adwia Co., Egypt) at a dose of $1 \mathrm{mg} / \mathrm{kg}$ BW given intramuscularly. General anesthesia was induced using ketamine $\mathrm{HCl}$ (Ketamine ${ }^{\circledR}$, Sigmatic, Egypt) at a dose of $10 \mathrm{mg} / \mathrm{kg} \mathrm{BW}$ and maintained by ketamine $\mathrm{HCl}$ according to Farghali et al. (2017).

\section{Surgical Operation}

Dogs were positioned in dorsal recumbence. The ventral abdominal mid-line laparotomy procedure at the umbilical region was performed according to Shariati et al. (2017).

\section{Partial Nephrectomy of the Right Kidney}

Model 1: About one-third of the right kidney mass was removed from the superior portion towards the middle of the pylorus as a modified technique according to Baracho et al. (2016) in rats (Fig. 1).

Model 2: Approximately one third was cut from the superior portion towards the middle of the pylorus and the other third from the inferior portion towards the pylorus according to Finco et al. (2004) in dogs and Devada et al. (2012) in Wister rat (Fig. 1).
Model 3: The renal artery was separated using fine blunt curved end microsurgical forceps, inserted between the artery and the vein, and opened progressively. Close to the pedicle, the renal artery sends out three branches, two of them were tied with two knots without sectioning according to Iliescu et al. (2006) and Villanueva et al. (2011) in rat and mice (Fig. 1).

The kidney was then placed in the abdominal cavity. The abdominal muscles were sutured at the ventral midline incision. The subcutaneous fat and fascia were closed with a second layer of sutures followed by the closure of the skin.

\section{Postoperative Care}

Food was withheld for the first 3 days and substitution fluid therapy (dextrose 5\% sol and Ringer's sol) was used. The animals were then fed on boiled rice and chicken. Prophylactic systemic antibiotic, SYNULOX® RTU (Clavulanic acid 35mg/ml and Amoxicillin 140mg/mL, Manufacturer: Zoetis, USA), was injected subcutaneously at a dose of $8.75 \mathrm{mg} / \mathrm{kg}$ bwt once daily for 5 days (Farghali et al. 2017). Ethanol spray for cleaning and topical antibiotic ointment (Fucidin ${ }^{\circledR} 20 \mathrm{mg} / \mathrm{g}$ Ointment, sodium fusidate, Leo Pharma A/S, Ballerup, Denmark) were applied on wounds three times daily and the skin sutures were removed 10 days post-operation (Gupta et al. 2019). The Elizabethan collar was applied for each dog as a nonpharmaceutical tool to avoid self-trauma and guard the operation site (Shenoda et al. 2020).

\section{Second Surgical Operation (Total Nephrectomy of Left Kidney)}

Two weeks after the first surgical operation, all animals of the three canine CKD models were subjected to contralateral nephrectomy. The laparotomy procedure was performed as previously described. The left kidney was exposed by elevating the mesocolon so that the small intestine is retracted to the animal's right side (Shariati et al. 2017). The left kidney was dissected from the surrounding organs. The first tie of the ligature knots was made towards the abdominal aorta side with double knots. The ligature knot was then applied towards the kidney side with double knots. The vessels were cut between the two knots without cutting the ligature knots according to Iliescu et al. (2006) and Wang et al. (2017). The incision was sutured and the Postoperative care of animals was applied as previously described (Fig. 1). The animals were kept under observation to record any abnormal signs.

\section{Ultrasonographic Examination}

Before animal euthanasia, the ultrasonographic examination was done in dorsal recumbence using a multifrequency $7.5 \mathrm{MHz}$ real-time curved transducer (Sonoace R3, Korea). At the diagnostic image unite, Department of Surgery, Anesthesiology, and Radiology, Faculty of Veterinary Medicine, Cairo University, Egypt.

\section{Biochemical Parameters}

Every week blood samples were collected from the jugular vein and 24-hours urine samples were collected by urethral catheterization to measure renal function parameters. Urea was measured using Spectrum kit (Egypt) according to Lile et al. (1957) and creatinine was measured by using Spectrum kit (Egypt) according to Fabiny and Eringhausen 
Int J Vet Sci, 2021, 10(4): 286-293.

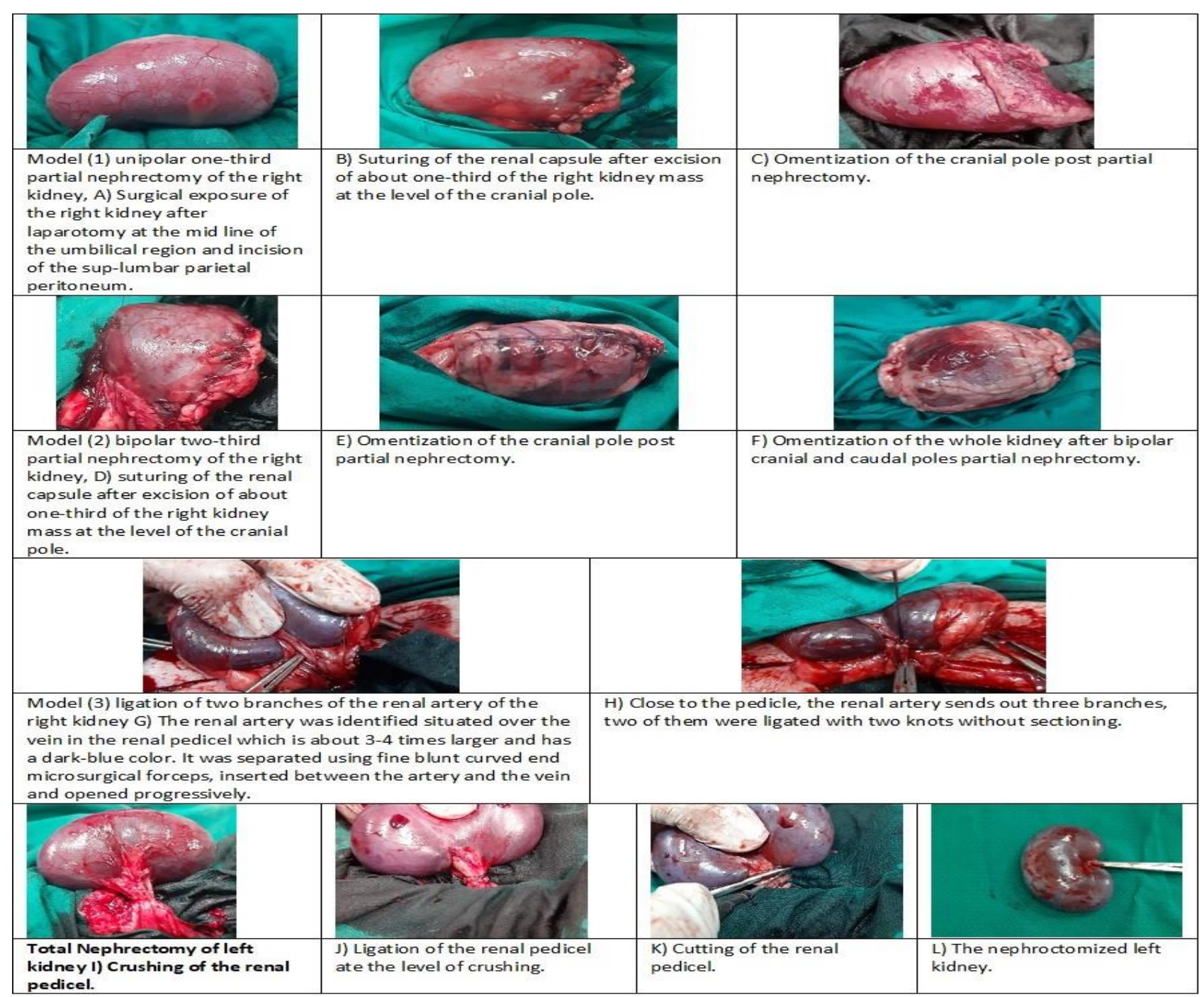

Fig. 1: Photographs of surgical operations performed; excision of one pole (A, B, C), excision of 2 poles (D, E, and F), ligation of two branches of renal arteries $(\mathrm{G}, \mathrm{H})$, and total nephrectomy of the left kidney (I, J, K, and L).

(1971) in which the creatinine is coupled with picric acid. The creatinine clearance was determined by multiplying the urine volume by the creatinine concentration in the urine, divided by serum creatinine using this equation:

Creatinine clearance $(\mathrm{mL} / \mathrm{min})=$ urinary volume $(\mathrm{mL} / \mathrm{min})$ $\times$ urinary creatinine $(\mathrm{mg} / \mathrm{dL}) /$ serum creatinine $(\mathrm{mg} / \mathrm{dL})$ (Borges et al. 2013).

\section{Histopathology}

Dogs were humanely euthanized by injection of $20 \%$ pentobarbital sodium solution and full saturated solution of potassium chloride intravenous according to Refaat et al. (2017) after 7 weeks from the first operation in models 1 and 2 and after 3 weeks in model 3 . Tissue specimens of the kidneys were collected from euthanized dogs and excised kidney poles from the first operation were collected as normal control. Tissues were fixed in $10 \%$ neutral buffered formalin, routinely processed, and embedded in paraffin according to standard procedures. Tissue sections (3-4 $\mu \mathrm{m})$ were prepared and stained with Hematoxylin and Eosin (Suvarna et al. 2013).

\section{Immunohistochemistry}

Immunohistochemistry of $\alpha$-SMA interstitial expression was performed on paraffin-embedded renal tissue after deparaffinization, rehydration, and antigen retrieval. The primary antibody against $\alpha$-SMA was applied (Novus Biologicals, Europe) and an avidin-biotinperoxidase complex kit was used according to manufacturer protocol (Dako; Carpinteria, CA) (Farghali et al. 2019). Image analysis was performed on 5 images with 200x magnification power using image $\mathrm{J}$.

\section{Real-time PCR for Kim-1 and NGAL Genes}

Frozen tissues of the right kidney from all models were homogenized and total RNA was extracted with RNA easy Mini Kit (Qiagen) and then quantity and quality were assessed by Beckman dual spectrophotometer (USA). High-capacity cDNA Reverse Transcriptase kit (Applied Biosystem, USA) was utilized to reverse transcription of extracted RNA. The amplification of cDNA was subsequently done by the Syber Green I PCR Master Kit (Fermentas) in a 48-well plate using the Step One instrument (Applied Biosystem, USA) as follows: 10min at $95^{\circ} \mathrm{C}$ for enzyme activation followed by 40 cycles of $15 \mathrm{~s}$ at $95^{\circ} \mathrm{C}, 20$ seconds at $55^{\circ} \mathrm{C}$ and $30 \mathrm{~s}$ at $72^{\circ} \mathrm{C}$ for the amplification step. Normalization for variation in the expression of each target gene was performed referring to the mean critical threshold (CT) values of $\beta$-actin housekeeping gene expression by the $\Delta \Delta \mathrm{Ct}$ method. $1 \mu \mathrm{M}$ 
of both primers specific for the target gene was utilized. Primers sequence for KIM1 gene was; forward 5'ATCTTTACCATTAGAGGGCT-3' and reverse 5'ACTGTCCTTCAGGTCAACAC-3' for NGAL gene was forward 5'- AGCAGCACGTAGGCAGAGCC -3' and reverse 5'- TGACCTCAAGGATAAGGCCA-3' and $\beta$ actin; forward 5'-CTAAGGCCAACCGTGAAAAG-3'and reverse 5'-GCCTGGATGGCTACGTACA-3'.

\section{RESULTS}

\section{Physical Statement and Clinical Signs}

Signs of kidney disease appeared after one week from the removal of the contralateral kidney. The dog in model 1 showed a slight decrease in food intake and water. It returned to its normal state after 7 weeks from the first operation.

The dog in model 2 showed a slight decrease in appetite and water intake that continued until 7 weeks from the first operation. It appeared dehydrated with losing body weight. On the other side, the dog in model 3 exhibited clinical signs as losing appetite, decreasing water intake followed by vomiting, and intermittent recumbence. For the management of the signs and pain reduction, the animal received daily a lactated Ringer's solution intravenously for rehydration, Enalapril maleate $10 \mathrm{mg}$ (Ezapril@, MultiApex Pharma (map) S.A.E. Egypt) orally in a dose rate of $0.5 \mathrm{mg} / \mathrm{kg}$ for management of hypertension, Omeprazole 20 mg (Pepzol®, Hikma Pharma S.A.E. Egypt) orally in a dose rate $1 \mathrm{mg} / \mathrm{kg}$ for the management of vomiting and fed on renal dry food diet ( $\mathrm{O}^{\prime} \mathrm{Neill}$ et al. 2013). Finally, the animal was euthanized three weeks post first operation as a humane endpoint interference. Postmortem examination of the kidneys from models 1 and 2 revealed normal textures with a pale color appearance, but the Kidney from model 3 appeared slightly small in size, indurated, and very pale.

\section{Biochemical Results \\ Serum Urea}

In model $1 \mathrm{dog}$, the serum urea level was increased till the 3 rd week then decreased gradually till the 7 th week. In model $2 \mathrm{dog}$, the serum urea increased gradually from the 1 st week to the 7 th week which showed the highest value $(70 \mathrm{mg} / \mathrm{dl})$. In model $3 \mathrm{dog}$, there was a progressive marked increase in serum urea than zero time from $1^{\text {st }}$ week to $3^{\text {rd }}$ week (Table 1).

\section{Serum Creatinine}

In model $1 \mathrm{dog}$, the serum creatinine level reached its peak $(1.86 \mathrm{mg} / \mathrm{dl})$ at the $3^{\text {rd }}$ week then gradually decreased to $1.18 \mathrm{mg} / \mathrm{dl}$ at the $7^{\text {th }}$ week. In model $2 \mathrm{dog}$, the serum creatinine was increased gradually till reached $2.92 \mathrm{mg} / \mathrm{dl}$ at the $7^{\text {th }}$ week. In model $3 \mathrm{dog}$, there was a marked elevation in serum creatinine levels from $1^{\text {st }}$ week after the first surgery until 3 weeks later (Table 2).

\section{Creatinine Clearance}

In model $1 \mathrm{dog}$, creatinine clearance level was markedly decreased than the zero-time level at the 3rd and 4th week then gradually increased till the 7 th week. In model $2 \mathrm{dog}$, the creatinine clearance was gradually decreased compared to the zero-time level and reached the lowest value at the 7 th week $(14.3 \mathrm{mg} / \mathrm{dl})$. In model $3 \mathrm{dog}$, there was a marked decrease in creatinine clearance levels than zero time from one week till the $3^{\text {rd }}$ week (Table 3 ).

\section{KIM-1gene \& NGAL Gene Expression Relative to $\beta$ - Actin}

The expression of Neutrophil gelatinase-associated Lipocalin (NGAL) and Kidney injury molecule-1 (KIM-1) genes increased in all models than normal. Model 1 renal tissue showed a slight increase than normal tissue whereas model 3 had the highest expression when compared to others (Table 4).

\section{Ultrasonography}

Abdominal ultrasound examination at the level of right sub-lumber region in model $1 \mathrm{dog}$ showed unipolar focal cortical and medullary hyperechogenicity of the cranial pole of the right kidney with a normal echogenic pattern of the middle third and caudal pole of the right kidney (Fig. 2a).

In model $2 \mathrm{dog}$, it revealed bipolar focal cortical and medullary hyperechogenicity of the right kidney with a normal echogenic pattern of the middle third of the right kidney (Fig. 2b). In model 3 dog, it showed diffused cortical and medullary hyperechogenicity of the right kidney with a reduction in kidney size (Fig. 2c).

\section{Histopathological Findings}

Kidney of -ve Control: Most examined sections showed normal glomeruli with normal renal tubules. Some examined sections revealed cellular casts inside the renal tubules (Fig. 3a).

Table 1: Serum urea level $(\mathrm{mg} / \mathrm{dl})$ in all experimental models

\begin{tabular}{lllllllll}
\hline Groups & \multicolumn{7}{c}{ Experimental Period (weeks) } & \\
\cline { 2 - 9 } & Zero time & $1^{\text {st }}$ & $2^{\text {nd }}$ & $3^{\text {rd }}$ & $4^{\text {th }}$ & $5^{\text {th }}$ & $6^{\text {th }}$ & $7^{\text {th }}$ \\
\hline Model 1 & 11 & 17 & 28 & 51 & 45 & 43 & 39 & 37 \\
Model 2 & 10 & 18 & 37 & 57 & 60 & 65 & 68 & 70 \\
Model 3 & 12 & 16 & 48 & 54 & & & & \\
\hline
\end{tabular}

Table 2: Serum creatinine level $(\mathrm{mg} / \mathrm{dl})$ in all experimental models

\begin{tabular}{llllllllc}
\hline Groups & \multicolumn{7}{c}{ Experimental Time } \\
\cline { 2 - 9 } & Zero time & $1^{\text {st }}$ & $2^{\text {nd }}$ & $3^{\text {rd }}$ & $4^{\text {th }}$ & $5^{\text {th }}$ & $6^{\text {th }}$ & $7^{\text {th }}$ \\
\hline Model 1 & 0.45 & 0.60 & 1.7 & 1.86 & 1.54 & 1.36 & 1.25 & 1.18 \\
Model 2 & 0.56 & 0.70 & 1.8 & 2.32 & 2.54 & 2.79 & 2.82 & 2.92 \\
Model 3 & 0.53 & 0.67 & 2.1 & 3.5 & & & & \\
\hline
\end{tabular}

Table 3: Creatinine clearance level $(\mathrm{ml} / \mathrm{min})$ in all experimental models

\begin{tabular}{llllllllc}
\hline Groups & \multicolumn{7}{c}{ Experimental Time } \\
\cline { 2 - 8 } & Zero time $1^{\text {st }}$ & $2^{\text {nd }}$ & $3^{\text {rd }}$ & $4^{\text {th }}$ & $5^{\text {th }}$ & $6^{\text {th }}$ & $7^{\text {th }}$ \\
\hline Model 1 & 66.3 & 59.8 & 25.6 & 22.6 & 21.3 & 23.6 & 24.5 & 25.5 \\
Model 2 & 66.8 & 55.53 & 18.3 & 17.5 & 16.3 & 14.9 & 14.8 & 14.3 \\
Model 3 & 69.8 & 56.8 & 11.5 & 9.1 & & & & \\
\hline
\end{tabular}

Table 4: KIM-1gene \&NGAL gene expression relative to $\beta$-actin in all experimental models

\begin{tabular}{lcc}
\hline Group & \multicolumn{2}{c}{ Genes expression } \\
\cline { 2 - 3 } & Kim-1 & NGAL \\
\hline Normal tissue & 1.162 & 1.573 \\
Model 1 & 1.682 & 1.9449 \\
Model 2 & 2.843 & 3.265 \\
Model 3 & 4.825 & 6.326 \\
\hline
\end{tabular}



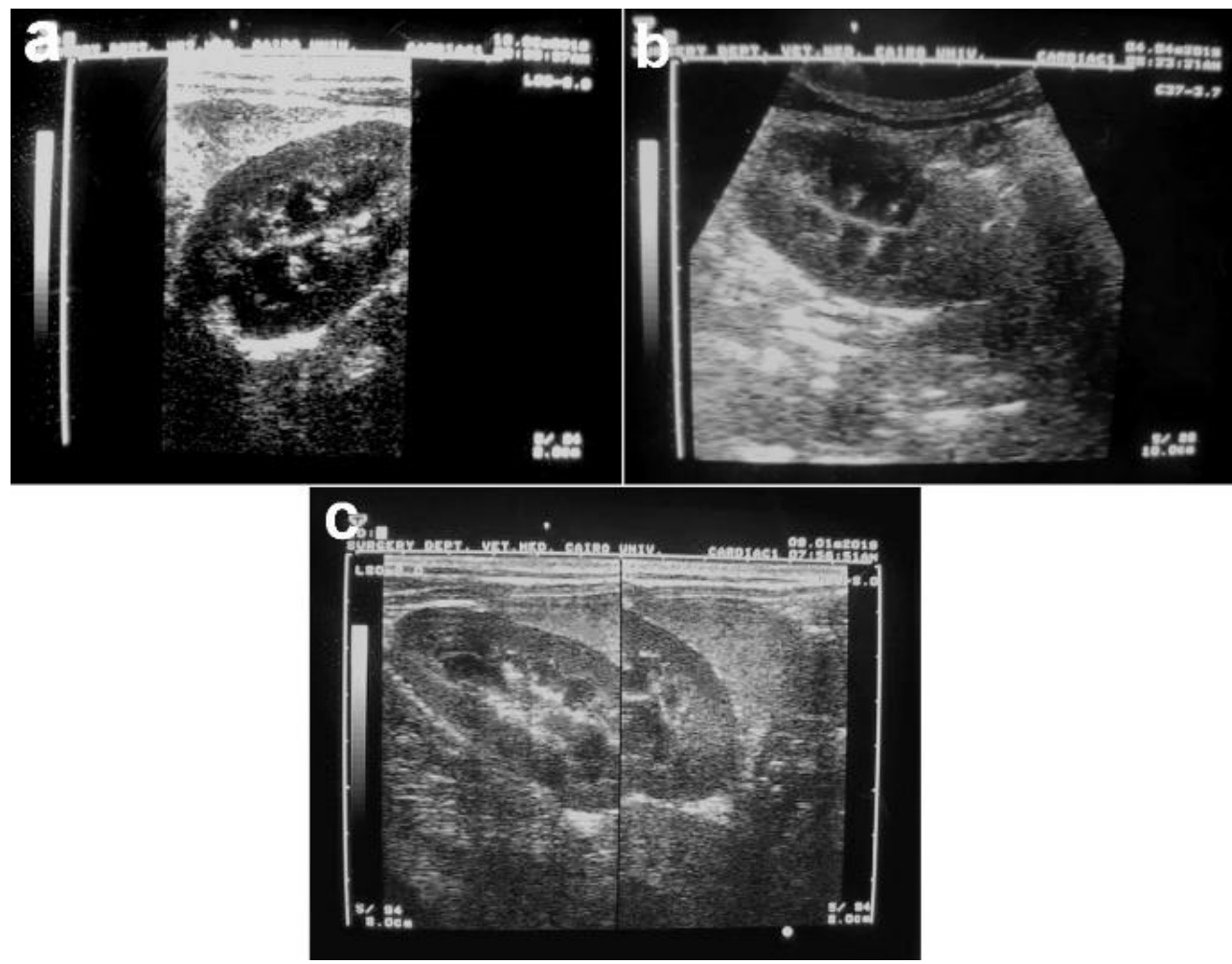

Fig. 2: Sagittal scan B-mode abdominal ultrasound image at the level of right sub-lumber region in (a) model 1 dog showing unipolar focal cortical and medullary hyperechogenicity of the cranial pole of the right kidney (reduced corticomedullary junction distinction) with a normal echogenic pattern of the middle third and caudal pole of the right kidney, (b) model 2 dog showing bipolar focal cortical and medullary hyperechogenicity of the right kidney (reduced corticomedullary junction distinction) with a normal echogenic pattern of the middle third of the right kidney, (c) model 3 dog showing diffused cortical and medullary hyperechogenicity of the right kidney (reduced corticomedullary junction distinction) with a reduction in the kidney size.

Model 1: The renal capsule showed severe thickening near the excised pole. Marked glomerular hypertrophy with increase hypercellularity was noted (Fig. 3b). The glomerular capillary tuft basement membrane was thickened narrowing the Bowman's space. Most examined sections of the kidney showed congestion of interstitial blood vessels with focal leukocytic cells infiltration in the interstitial tissue. Interstitial hemorrhage with necrobiotic changes in renal tubules was noted in the renal medulla.

Model 2: Most examined sections showed marked focal interstitial fibrosis with mononuclear inflammatory cells infiltration in the cortex and medulla. The fibrous C.T proliferation was mainly seen around glomeruli and blood vessels (Fig. 3c). Most of the glomeruli were shrunken leaving dilated Bowman's space containing proteinaceous material. Some renal tubules appeared necrotic, atrophied, or with vacuolar degeneration in their lining epithelium. Others showed cystic dilatation, tubular casts, and calcification. Marked renal vein dilatation with fibrin clots inside was observed.

Model 3: The renal tissue in this model showed severe fibrosis of renal capsule and interstitial tissue. A prominent infarcted area was noted well demarcated with leucocytes (Fig. 3d). Most examined renal blood vessels showed hypertrophy of their walls and perivascular edema was noted.

\section{IHC Results}

The damage marker $\alpha$-SMA was expressed in the myofibroblasts. Normal tissue showed normal IHC distribution of this marker $2.1 \pm 0.5$ (Fig. 4a). However, SMA was mildly expressed in model $1 \mathrm{dog} 4.1 \pm 0.04$ (Fig. $4 b)$, moderately distributed (14.9 \pm 2.4$)$ in renal parenchyma of model 2 dog (Fig. 4c) and was widely distributed in the renal parenchyma of model $3 \mathrm{dog}$ by image analysis (21.6 \pm 1.3$)$ (Fig. 4d)

\section{DISCUSSION}

The induction of suitable CKD experimental models remains a challenge. An ideal experimental animal model provides a stable uremic state which facilitates experimental manipulation. In the present study, three distinct degrees of uremic dogs with various degrees of glomerulointerstitial fibrosis were obtained by surgical induction.

Model 1 dog showed mild uremia, the serum creatinine level reached its peak at the 3rd week then gradually decreased till the 7th week as the normal remnant nephrons underwent compensatory function. According to the staging system based on the level of serum creatinine concentration developed by IRIS (International Renal Interest Society) (Grauer 2015) model 1 dog can be considered in stage one of CKD. The creatinine clearance in model $1 \mathrm{dog}$ at 7 weeks from CKD induction was reduced by about $40 \%$ than its zero-time level partially agreeing with previous studies in rats and mice (Fujihara et al. 2007; Sun et al. 2011). Mild injury of the right kidney was confirmed by abdominal ultrasonography, histopathology, weak expression of $\alpha$-SMA marker in the interstitial tissue and low expression of KIM-1 gene and 


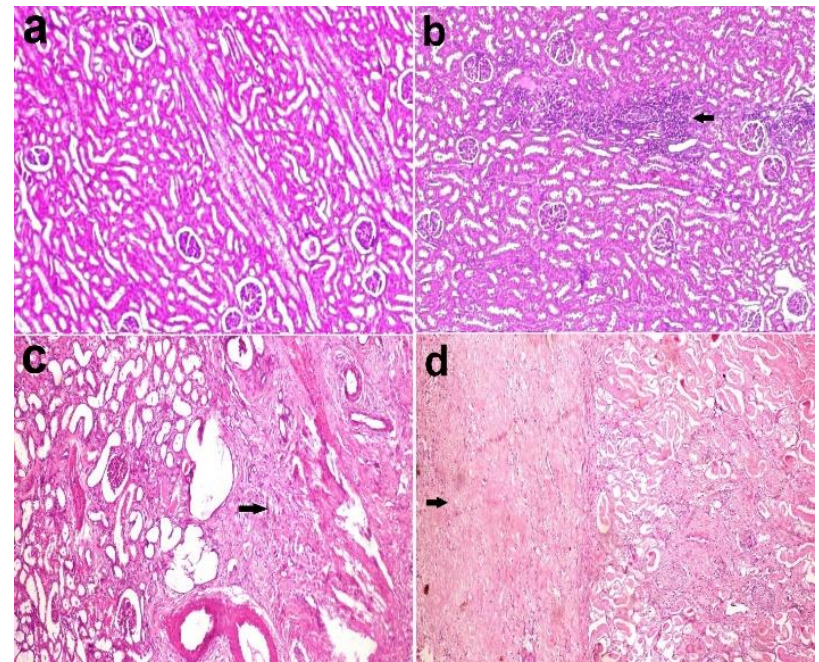

Fig. 3: Kidney, dog. (a) Normal glomeruli and renal tubules in the control dog. (b) Hypertrophy of glomeruli with focal leukocytic cells infiltration in the interstitial tissue (arrow) in model $1 \mathrm{dog}$. (c) Cortical interstitial fibrosis (arrow), cystic dilatation of some renal tubules, and glomerular atrophy in model 2 dog. (d) Severe thickening of the renal capsule (arrow) and infarcted area in model 3 dog. Haematoxylin and eosin stain. 100X.

NGAL gene which are sensitive and specific biomarkers of kidney injury (Rees and Kain 2008; Yin and Wang 2016). Similarly, a previous study on rats showed that the degree of impairment was directly related to the severity of the renal excision (Baracho et al. 2016).

Model 2 dog showed a moderate and gradual increase in serum urea and creatinine levels. It can be classified as stage 3 of CKD according to the staging system developed by IRIS. It suffered from moderate progressive loss of glomerular filtration rate (GFR) as after 7 weeks from the first surgical operation, the creatinine clearance was reduced by about $52 \%$ than its zero-time level. Previous studies also recorded about $50 \%$ decrease in creatinine clearance in rats and mice after four weeks from $5 / 6$ nephrectomy (Fujihara et al. 2007; Sun et al. 2011). Furthermore, bipolar focal cortical and medullary hyperechogenicity of the right kidney was observed in ultrasonography which is probably due to renal fibrosis (Nogueira et al. 2016). This was also confirmed by histopathology and immunohistochemistry of $\alpha$-SMA in which moderate glomerular hypertrophy with interstitial fibrosis was observed. Similar to the current study, hypertrophy of remnant glomeruli, mesangial expansion, increased glomerular collagen deposition in mice with 5/6 nephrectomy (Gava et al. 2012), and tubulointerstitial changes in rats with subtotal nephrectomy were observed (Devada et al. 2012 and Baracho et al. 2016). In dogs, CKD induction resulted in stable chronic renal failure until 9-12 months (Vaneerdeweg et al. 1992), high serum creatinine concentration which was $4.3 \pm 1.5 \mathrm{mg} / \mathrm{dL}$ (Steiner et al. 2010), mesangial hyperplasia, and focal glomerular sclerosis (Bourgoignie et al. 1987).

The structural and functional adaptive changes after a significant reduction of the renal mass are responsible for the pathological processes and the production of interstitial fibrosis in the remnant kidney model (Perico et al. 2005; Fujihara et al. 2007; Sun et al. 2011).

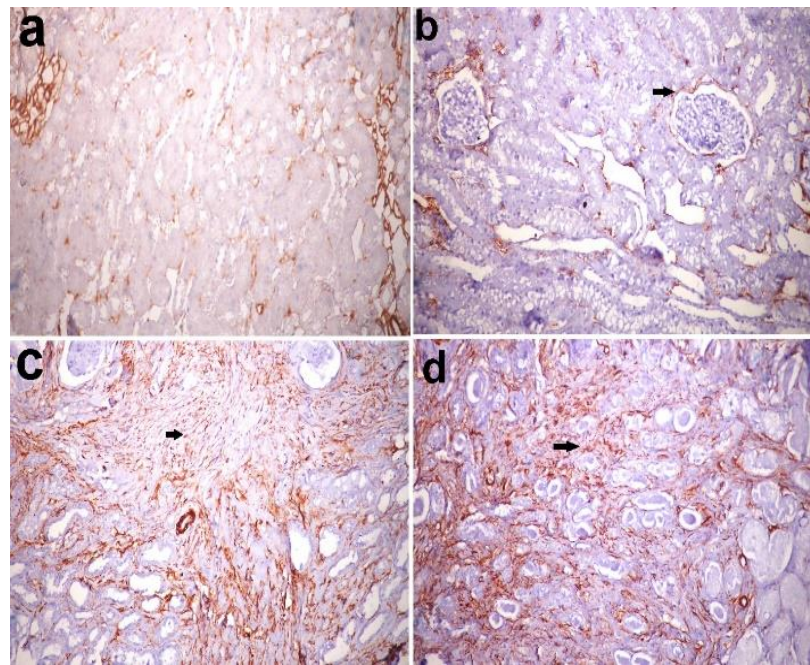

Fig. 4: Kidney, dog. (a) Weak expression of $\alpha$-SMA in the interstitial tissue in control tissue. (b) Weak expression of $\alpha$-SMA in periglomerular (arrow) and interstitial tissue after excision of one kidney pole in model 1 dog. (c) Moderate expression of $\alpha$ SMA in periglomerular and interstitial tissue (arrow) after excision of two kidney poles in model 2 dog. (d) Severe expression of $\alpha$ SMA in the interstitial tissue (arrow) after ligation of two renal arterial branches in model 3 dog. Immunoperoxidase. X200.

On the other hand, model 3 dog exhibited the most rapid and highest elevation of serum urea and creatinine levels and therefore the animal suffered from severe uremia. According to the staging system developed by IRIS, we couldn't define which CKD stage was it as it didn't reach stability. A stable creatinine is defined by documentation of $<20 \%$ variability in serum creatinine when measured again on at least 2 occasions along two weeks (Grauer 2015). These results agreed with Liu et al. (2003) who described that in rats the standard deviation of blood urea nitrogen and creatinine in the infarction model was substantially higher than that obtained from the surgical resection model.

It was shown that the vascular ligation model had significant proteinuria, hypertension, and glomerulosclerosis than surgical mass reduction models (Griffin et al. 2000; Liu et al. 2003). KIM-1 gene and NGAL gene were expressed at a high level in model $3 \mathrm{dog}$. The high expression of KIM-1 is associated with increased expression of $\alpha$-SMA, inflammation, pre-fibrotic areas, and renal fibrosis. Also, chronically damaged tubular cells produce a great quantity of NGAL (Bolignano et al. 2008) Serum NGAL acts as a kidney injury biomarker but not in all experimental animal models as reported previously (Wang et al. 2020). In the present study, the expression of NGAL gene increased with the increase of kidney injury.

The ligation technique is simple but the results in dogs are unpredictable due to formation of collateral vessels which bypass the ligated branches (Vaneerdeweg et al. 1992). however, Liang et al. (2014) reported that ligation of renal arteries can lead to complete infarction, with damage to afferent and efferent nerves in the adventitia of the renal artery and area of the renal hilus.

\section{Conclusion}

The best technique for developing a model of canine CKD with persistent uremia is $5 / 6$ nephrectomy by 
excision of two kidney poles. The dog in this model became uremic and remained stable for a long time which would allow experimental manipulation.

\section{Author's Contribution}

HE conceived the original idea and designed the study. TI and HF carried out the experiment. HF carried out the surgery. MK and TI performed the histopathology and immunohistochemistry. DS performed the gene expression. TI wrote the manuscript with support from HE, MK, HF and EI. HE supervised the experiment. All authors revised and approved the final manuscript.

\section{REFERENCES}

Adams LG, Polizin DJ, Osborne CA, O'Brien TD and Hostetter $\mathrm{TH}, 1994$. Influence of dietary protein /calorie intake on renal morphology and function in cats with 5/6 nephrectomy. Laboratory Investigation 70: 347-357.

Baracho NCV, Kangussu LM, Prestes TRR, Silveira KD, Pereira RM, Natália Pessoa Rocha NP and Silva ANS, 2016. Characterization of an experimental model of progressive renal disease in rats. Acta Cirúrgica Brasileira 31:744-752. http://doi.org/10.1590/S0102-865020160110000007

Bigliardi P, Langer S, Cruz J, Kim SW, Nair H and Srisawasdi G, 2017. An Asian perspective on povidone iodine in wound healing. Dermatology 233: 223-233. https://doi.org/10.1159/ $\underline{000479150}$

Bolignano D, Donato V, Coppolino G, Campo S, Buemi A, Lacquaniti A and Buemi M, 2008. Neutrophil GelatinaseAssociated Lipocalin (NGAL) as a marker of kidney damage. American Journal of Kidney Diseases 52: 595-605. https://doi.org/10.1053/j.ajkd.2008.01.020

Bourgoignie JJ, Gavellas G, Martinez E and Pardo V, 1987. Glomerular function and morphology after renal mass reduction in dogs. Journal of Laboratory Clinical Medicine 109: 380-388.

Borges M, Filho RM, Laposy CB, Guimaraes-Okamoto PTC, Chaves MP and Melchert A, 2013. Nonsteroidal antiinflammatory therapy.changes on renal function of healthy dogs. Acta Cirúrgica Brasileira 28: 842-847. https://doi.org/ 10.1590/S0102-86502013001200006

Chakrabarti S, Syme HM and Brown CA, 2013. Histomorphometry of feline chronic kidney disease and correlation with markers of renal dysfunction. Veterinary Pathology 50:147-155. https://doi.org/10.1177/03009858

Chen R, Wang L, Liu S, Chen X, Hu Y, Liu H, Zhang H, Jiang H, Wang Q, Ye D, Li L, Liu D, Pan X, Wei L, Li X and Zhang $\mathrm{X}, 2017$. Bcl-3 is a novel biomarker of renal fibrosis in chronic kidney disease. Oncotarget 8: 97206-97216. https://doi/10.18632/oncotarget.21692

Chow KM, Liu ZC and Chang TM, 2003. Animal remnant kidney model of chronic renal failure revisited. Hong Kong Journal of Nephrology 5: 57-64. https://doi.org/10.1016/S15615413(09)60109-5

Devada S, Patel M, Mishra V, Ranvir R, Sundar R and Jain M, 2012. Novel model for renal failure and anaemia induced by $5 / 6$ nephrectomy in Wistar rat. International Journal of Veterinary Science 1: 83-88.

Fabiny DL and Eringhausen G, 1971. Calorimeteric method for estimation of creatinine. Clinical Chemistry 17: 696.

Farghali HA, AbdElKader NA, Khattab MS and AbuBakr HO, 2017. Evaluation of subcutaneous infiltration of autologous platelet-rich plasma on skin-wound healing in dogs. Bioscience reports 37: 1-14. https://doi.org/10.1042/BSR $\underline{20160503}$

Farghali HA, AbdElkadr NA, AbuBakr HO, Aljuaydi SH, Khattab MS, Elhelw R and Elhariri M, 2019. Antimicrobial action of autologous platelet-rich plasma on MRSA-infected skin wounds in dogs. Scientific reports 9:12722. https://doi.org/10.1038/s41598-019-48657-5

Farghali HA, AbdElKader NA, Khattab MS and AbuBakr HO, 2017. Novel approach to gastric mucosal defect repair using fresh amniotic membrane allograft in dogs (experimental study). Stem Cell Research \& Therapy 8: 235. https://doi.org/10.1186/s13287-017-0682-3

Finco DR, 2004. Association of systemic hypertension with renal injury in dogs with induced renal failure. Journal of Veterinary Internal Medicine 18: 289-294. https://doi.org/ 10.1111/j.1939-1676.2004.tb02547.x

Fujihara CK, Malheiros DM and Zatz R, 2007. Losartanhydrochlorothiazide association promotes lasting blood pressure normalization and completely arrests long-term renal injury in the 5/6 ablation model. American Journal of Physiology Renal Physiology 292: 1810-1818. https://doi.org/10.1152/ajprenal.00521.2006

Gava AL, Freitas PS, Balarini CM, Vasquez EC and Meyrelles SS, 2012. Effects of 5/6 nephrectomy on renal function and blood pressure in mice. International Journal of Physiology Pathophysiology and Pharmacology 4: 167-173.

Grauer GF, 2015. Feline friendly article: feline chronic kidney disease. Today's Veterinary Practice 5: 36-41.

Griffin KA, Picken MM, Churchill M, Churchill P and Bidani AK, 2000. Functional and structural correlates of glomerulosclerosis after renal mass reduction in the rat. Journal of the American Society of Nephrology 11: 497-506.

Gupta V, Kumar S and Vyas KC, 2019. Skin preparation for the prevention of surgical site infection: Efficacy of sodium fusidate and ethanol spray over conventional methods. International Journal of Surgery Science 3: 82-85. https://doi.org/10.33545/surgery.2019.v3.i4b.221

Iliescu R, Yanes LL, Vera T, Sartori-valinotti JC, Williams J, Stec DE and Reckelhoff JF, 2006. Testeosterone supplements exacerbate renal injury in hypertensive rats with reduced renal mass. The Federation of American Societies for Experimental Biology Journal 20: A1192. https://doi.org/ 10.1096/fasebj.20.5.A1192-c

Liang Z, Liu LF, Chen XP, Shi XM, Guo HY, Lin K, Guo JP, Shan ZL and Wang YT, 2014. Establishment of a model of renal impairment with mild renal insufficiency associated with atrial fibrillation in canines. PLoS One 9:e105974. https://doi.org/10.1371/journal.pone.0105974

Lile EC, Villamil MF, Rhees MC and Scribner BH, 1957. Bedside determination of urea nitrogen level in serum or plasma. JAMA 164: 277-279. https://doi.10.1001/jama.1957.62980 030001013

Liu ZC, Chow KM and Chang TM, 2003. Evaluation of two protocols of uremic rat model: partial nephrectomy and infarction. Renal Failure 25: 935-943. https://doi.org/ 10.1081/JDI-120026028

Lorsirigool A and Pumipuntu N, 2020. A Retrospective Study of Dogs Infected with Ehrlichia canis from 2017-2019 in the Thonburi Area of Bangkok Province, Thailand. International Journal of Veterinary Science 2020, 9: 578580. https://doi.org/10.37422/IJVS/20.062

McLeland S, Cianciolo RE and Duncan CG, 2014. Comparison of biochemical and histopathological staging in cats with chronic kidney disease. Veterinary Pathology 52: 524-534. https://doi.org/10.1177/0300985814561095

Mitchell K, Barletta M, Quandt, J, Shepard M, Kleine S and Hofmeister E, 2018. Effect of routine pre-anesthetic laboratory screening on pre-operative anesthesia-related decision-making in healthy dogs. La revue Veterinaire Canadienne 59: 773-778.

Nogueira A, Rocha AF, Ginja M, Oliveira PA and Pires MJ, 2016. Ultrasonographic evaluation of the kidney in $5 / 6$ nephrectomized rats: correlation with biochemical and histopathological findings. In vivo 30: 829-834. https://doi: 10.21873/invivo.11001 
O’Neill DG, Elliott J, Church DB, McGreevy PD, Thomson PC and Brodbelt DC, 2013. Chronic kidney disease in dogs in the UK, veterinary practices: Prevalence, risk factors, and survival. Journal of Veterinary Internal Medicine 27: 814821. https://doi.org/10.1111/jvim. 12090

Perico N, Codreanu I, Schieppati A and Remuzzi G, 2005. Pathophysiology of disease progression in proteinuric nephropathies. Kidney International 67: S79-S82. https://doi:10.1111/j.1523-1755.2005.09420.x

Rees AJ and Kain R, 2008. Kim-1/Tim-1: From biomarker to therapeutic target? Nephrology Dialysis Transplantation 23: 3394-3396. https://doi:10.1093/ndt/gfn480

Refaat MM, Zickri MB, Fares AE, H Gabr, EL-Jaafary SI, Mahmoud BE, Madbouly MA, Abdelfadel MA, Hammad AM and Farghali HA, 2017. Enhancement of neural regeneration after spinal cord injury using muscle graft in experimental dogs. International Journal of Clinical and Experimental Pathology 10: 9330-9340.

Ruiz-Ortega M, Rayego-Mateos S, Lamas S, Ortiz A and Rodrigues-Diez RR, 2020. Targeting the progression of chronic kidney disease. Nat Rev Nephrol 16: 269-288. https://doi.org/10.1038/s41581-019-0248-y

Shariati E, Bakhtiari J, Khalaj A, Molazem M, Shariati E and Niasari-Naslaji A, 2017. Clinical and paraclinical evaluation of partial nephrectomy using laparoscopy and open surgery in dogs: new suturing technique. Iranian Journal of Veterinary Research 18: 1-5.

Shenoda Y, Ward MP, McKeegan D and Fawcett A, 2020. The Cone of Shame: Welfare implications of Elizabethan collar use on dogs and cats as reported by their owners. Animals 10: 333. https://doi.org/10.3390/ani10020333

Sparkes AH, Caney S, Chalhoub S, Elliott J, Finch N and Gajanayake I, 2016. ISFM consensus guidelines on the diagnosis and management of feline chronic kidney disease. Journal of Feline Medicine and Surgery 18: 219-239. https://doi: 10.1177/1098612X16631234

Sun L, Zhang D, Liu F, Xiang X, Ling G, Xiao L, Liu Y, Zhu X, Zhan M, Yang Y, Kondeti VK and Kanwar YS, 2011. Lowdose paclitaxel ameliorates fibrosis in the remnant kidney model by down-regulating miR-192. Journal of Pathology 25: 364-377. https://doi.org/10.1002/path.2961

Suvarna K, Layton C, Bancroft JD, 2013. Bancroft's Theory and Practice of Histological Technique. 7th Churchill Livingstone, Edinburgh.

Steiner JM, Finco DR, and Williams DA, 2010. Serum lipase activity and canine pancreatic lipase immunoreactivity
(cPLI) concentration in dogs with experimentally induced chronic renal failure. Veterinary Research 3: 58-63. https://doi:10.3923/vr.2010.58.63

Togel F, Cohen A, Zhang P, Yang Y, Hu Z and Westenfelder C, 2008. Autologous and allogeneic marrow stromal cells are safe and effective for the treatment of acute kidney injury. Stem Cells and Development 18: 475-485. https://doi: $10.1089 / \mathrm{scd} .2008 .0092$

Tomino Y, 2014. Pathogenesis and Treatment of Chronic Kidney Disease: A Review of Our Recent Basic and Clinical Data. Kidney Blood Pressure Research 39: 450-489. https://doi.org/10.1159/00368458

Vaneerdeweg W, Buyssens N, Winne T, Sebrechts M and Arakelian S, 1992. A standardized surgical technique to obtain a stable and reproducible chronic renal failure model in dogs. European Surgical Research 24: 273-282. https://doi.org/10.1159/000129216

Vázquez-Méndez E, Gutiérrez-Mercado Y, Mendieta-Condado E, Javier Gálvez-Gastélum F, Hugo Esquivel-Solís, SánchezToscano Y, Morales-Martínez C, Canales-Aguirre AA and Márquez-Aguirre AL, 2020. Recombinant Erythropoietin Provides Protection against Renal Fibrosis in AdenineInduced Chronic Kidney Disease", Mediators of Inflammation 2020: Article D 8937657, 11 pages. https://doi.org/10.1155/2020/8937657

Villanueva S, Ewertz E, Flavio CF, Tap P, Azabal CI, Juan E Carre $\tilde{n}$ JE, Figueroa F and Vio CP, 2011. Mesenchymal stem cell injection ameliorates chronic renal failure in a rat model. Clinical Science 121: 489-499. https://doi.org/ 10.1042/ CS20110108

Wang W, Li Z, Chen Y, Wu H, Zhang S and Chen X, 2020. Prediction Value of Serum NGAL in the Diagnosis and Prognosis of Experimental Acute and Chronic Kidney Injuries. Biomolecules 10: 981. https://doi:10.3390/biom 10070981

Wang X, Chaudhry MA, Nie Y, Xie Z, Shapiro JI and Liu J, 2017. A Mouse 5/6th nephrectomy model that induces experimental uremic cardiomyopathy. Journal of Visualized Experiments 129: e55825. https://doi:10.3791/55825

Yin C and Wang N, 2016. Kidney injury molecule-1 in kidney disease. Renal Failure 38: 1567-1573. https://doi:10.1080/ $\underline{0886022 X .2016 .1193816}$

Yu J, Mao S, Zhang Y, Gong W, Jia Z, Huang S and Zhang A, 2016. MnTBAP Therapy attenuates renal fibrosis in mice with 5/6 nephrectomy. Oxidative Medicine and Cellular Longevity 2016: Article ID 7496930. http://dx.doi.org/ $\underline{10.1155 / 2016 / 7496930}$ 